\title{
GCU
}

Glasgow Caledonian

University

University for the Common Good

\section{Pelvic floor muscle training for secondary prevention of pelvic organ prolapse (PREVPROL): a multicentre randomised controlled trial}

Hagen, Suzanne; Glazener, Cathryn; McClurg, Doreen; Macarthur, Christine; Elders, Andrew; Herbison, Peter; Wilson, Don; Toozs-Hobson, Philip; Hemming, Christine; Hay-Smith, Jean; Collins, Marissa; Dickson, Sylvia; Logan, Janet

Published in:

Lancet

DOI:

10.1016/S0140-6736(16)32109-2

Publication date:

2017

Document Version

Author accepted manuscript

Link to publication in ResearchOnline

Citation for published version (Harvard):

Hagen, S, Glazener, C, McClurg, D, Macarthur, C, Elders, A, Herbison, P, Wilson, D, Toozs-Hobson, P, Hemming, C, Hay-Smith, J, Collins, M, Dickson, S \& Logan, J 2017, 'Pelvic floor muscle training for secondary prevention of pelvic organ prolapse (PREVPROL): a multicentre randomised controlled trial', Lancet, vol. 389, no. 10067, pp. 393-402. https://doi.org/10.1016/S0140-6736(16)32109-2

\section{General rights}

Copyright and moral rights for the publications made accessible in the public portal are retained by the authors and/or other copyright owners and it is a condition of accessing publications that users recognise and abide by the legal requirements associated with these rights.

Take down policy

If you believe that this document breaches copyright please view our takedown policy at https://edshare.gcu.ac.uk/id/eprint/5179 for details of how to contact us. 
Title: A multicentre randomised controlled trial of a pelvic floor muscle training intervention for the secondary prevention of pelvic organ prolapse (PREVPROL)

\author{
Authors: Hagen S, Glazener C, McClurg D, Macarthur C, Elders A, Herbison P, Wilson D, Toozs- \\ Hobson P, Hemming C, Hay-Smith J, Collins M, Dickson S, Logan J
}

\begin{tabular}{|c|c|}
\hline $\begin{array}{l}\text { Professor Suzanne Hagen, PhD (corresponding } \\
\text { author) } \\
\text { Professor of Health Services Research } \\
\text { Nursing, Midwifery and Allied Health Professions } \\
\text { Research Unit } \\
\text { Glasgow Caledonian University } \\
\text { Cowcaddens Road } \\
\text { Glasgow G4 0BA } \\
\text { Email: s.hagen@gcu.ac.uk } \\
\text { Telephone: }+441413318100 / 4\end{array}$ & $\begin{array}{l}\text { Professor Cathryn Glazener, PhD } \\
\text { Professor of Health Services Research } \\
\text { Health Services Research Unit } \\
\text { University of Aberdeen, Health Sciences Building, } \\
\text { Foresterhill, Aberdeen AB25 2ZD }\end{array}$ \\
\hline $\begin{array}{l}\text { Professor Doreen McClurg, PhD } \\
\text { Professor of Physiotherapy } \\
\text { Nursing, Midwifery and Allied Health Professions } \\
\text { Research Unit } \\
\text { Glasgow Caledonian University } \\
\text { Cowcaddens Road } \\
\text { Glasgow G4 OBA }\end{array}$ & $\begin{array}{l}\text { Professor Christine MacArthur, PhD } \\
\text { Professor of Maternal and Child Epidemiology } \\
\text { Department of Epidemiology and Biostatistics } \\
\text { University of Birmingham, } \\
\text { Birmingham B15 2TT }\end{array}$ \\
\hline $\begin{array}{l}\text { Andrew Elders, MSc } \\
\text { Senior Statistician } \\
\text { Nursing, Midwifery and Allied Health Professions } \\
\text { Research Unit } \\
\text { Glasgow Caledonian University } \\
\text { Cowcaddens Road } \\
\text { Glasgow G4 OBA }\end{array}$ & $\begin{array}{l}\text { Professor Peter Herbison, DSc } \\
\text { Professor of Biostatistics } \\
\text { Preventive and Social Medicine } \\
\text { Dunedin School of Medicine, PO Box 913, Dunedin } \\
\text { 9054, New Zealand }\end{array}$ \\
\hline $\begin{array}{l}\text { Professor Don Wilson, MD } \\
\text { Emeritus Professor of Obstetrics and Gynaecology } \\
\text { Department of Women's and Children's } \\
\text { Dunedin School of Medicine, PO Box 913, Dunedin } \\
\text { 9054, New Zealand }\end{array}$ & $\begin{array}{l}\text { Dr Philip Toozs-Hobson, MD } \\
\text { Consultant Urogynaecologist } \\
\text { Department of Urogynaecology } \\
\text { Birmingham Women's Hospital, Mindohlsen Way, } \\
\text { Birmingham B152TG }\end{array}$ \\
\hline $\begin{array}{l}\text { Dr Christine Hemming, MD } \\
\text { Consultant Obstetrician and Gynaecologist } \\
\text { Obstetrics and Gynaecology } \\
\text { Aberdeen Royal Infirmary, Foresterhill, Aberdeen }\end{array}$ & $\begin{array}{l}\text { Jean Hay-Smith, PhD } \\
\text { Associate Professor } \\
\text { Rehabilitation Teaching \& Research Unit } \\
\text { Department of Medicine } \\
\text { University of Otago, Wellington } \\
\text { PO BOX } 7343 \\
\text { New Zealand }\end{array}$ \\
\hline $\begin{array}{l}\text { Marissa Collins, MSc } \\
\text { Researcher in Health Economics } \\
\text { Yunus Centre for Social Business and Health } \\
\text { Glasgow Caledonian University } \\
\text { Cowcaddens Road } \\
\text { Glasgow G4 OBA }\end{array}$ & $\begin{array}{l}\text { Sylvia Dickson, BSc } \\
\text { Research Fellow } \\
\text { School of Health and Life Sciences } \\
\text { Glasgow Caledonian University } \\
\text { Cowcaddens Road } \\
\text { Glasgow G4 OBA }\end{array}$ \\
\hline
\end{tabular}


Janet Logan, MA

Research Assistant

Nursing, Midwifery and Allied Health Professions

Research Unit

Glasgow Caledonian University

Cowcaddens Road

Glasgow G4 OBA 


\section{Abstract}

Background: Pelvic floor muscle training (PFMT) in women seeking treatment for prolapse reduces prolapse severity and symptoms. PFMT may also be effective in secondary prevention of prolapse and the need for future treatment.

Methods: We conducted a parallel-group, multicentre, randomised controlled trial in women from a longitudinal study of pelvic floor function after childbirth. Eligible women had stage I to III prolapse but had not sought treatment. Those with major stages of prolapse (stage IV), or no prolapse (stage 0 ), were excluded. Women were randomly assigned (1:1), by remote computer allocation, to receive one-to-one PFMT (five physiotherapy appointments over 16 weeks, and annual review) plus Pilatesbased PFMT classes and a DVD for home use (intervention group), or a lifestyle advice leaflet for women with prolapse (control group). Women and intervention physiotherapists could not be blinded to treatment. The primary outcome was self-report of prolapse symptoms (Pelvic Organ Prolapse Symptom Score, POP-SS) at two years, with lower scores indicating fewer symptoms.

Findings: 414 women were randomised (207 intervention, 207 control), with one postrandomisation exclusion per group (206 per group analysed). At baseline, 97\% of women had prolapse above or at the hymen. Mean POP-SS score at two years was 3.2 (SD 3.4) for the intervention group, significantly lower than the control group (mean 4.2 (SD 4.4)), adjusted mean difference $-1.01(95 \% \mathrm{Cl}-1.70$ to -0.33$)$. The mean symptom score stayed similar across time-points in the control group, but decreased in the intervention group. Uptake of further treatment for prolapse within two years was less common in the intervention group (5.9\% vs $14.4 \%$, OR $=0.29$ (95\% $\mathrm{Cl} 0.12$ to 0.71 ), $p=0.007$ ). Three adverse events occurred in the intervention group (one fall, one pain in tail bone, one chest pain and shortness of breath).

Interpretation: We provide evidence that PFMT leads to a small, but likely important reduction in prolapse symptoms, and lower uptake of prolapse treatment. This is important information for women and caregivers considering preventive strategies. 


\section{Introduction}

Pelvic organ prolapse is the symptomatic descent of one or more of the anterior vaginal wall, posterior vaginal wall, the uterus (cervix), or the apex of the vagina from the normal anatomical position, ${ }^{1}$ caused by herniation through deficient pelvic fascia, or weaknesses or deficiencies in the ligaments or muscles which should support the pelvic organs. Associated symptoms include a sensation of vaginal bulge, something coming down, urinary, bowel and sexual dysfunction, and backache. In one study of 27,000 post-menopausal women, $40 \%$ had some degree of prolapse. ${ }^{2} \mathrm{~A}$ woman's lifetime risk of undergoing surgery for prolapse or related urinary incontinence has been estimated as 7\% and 11\%. ${ }^{3}$ In 2012-13 in England, 35,094 women were admitted to hospital with a main diagnosis of female genital prolapse with 29,618 operations performed ${ }^{4}$.

Pelvic floor muscle training (PFMT) is often recommended for prolapse treatment, and theoretically may prevent prolapse progressing and becoming symptomatic. Borello-France ${ }^{5}$ found women with stage II prolapse (within $+/-1 \mathrm{~cm}$ of the hymen) were better able to elevate their pelvic floor than those with stage III or IV prolapse, and hypothesised that weak pelvic floor muscles (PFMs) may be a contributory factor in preventing prolapse development. However the lack of trials evaluating the role of PFMT in prolapse prevention has been highlighted. ${ }^{6}$ Conversely clear evidence of the clinical and cost-effectiveness of PFMT in the treatment of established prolapse is now available from two recent randomised controlled trials (RCT). ${ }^{7,8}$

PREVPROL, a secondary prevention trial, ${ }^{9}$ aimed to determine clinical and cost-effectiveness of PFMT to prevent prolapse symptoms, worsening prolapse severity and uptake of prolapse treatment. This paper specifically reports symptoms and uptake of treatment in the first two years. We plan to report longer-term outcomes, including prolapse severity, when data become available.

\section{Methods}

\section{Study design and participants}

This was a three-centre (Dunedin New Zealand, Aberdeen and Birmingham UK), parallel-group RCT (1:1 allocation) of PFMT versus control (prolapse lifestyle advice leaflet) in the secondary prevention of prolapse. Participants had been involved in a longitudinal study of women after an index birth occurring between October 1993 to September 1994 (ProLong). ${ }^{10}$ At 12 year follow-up these women were invited to have a POP-Q (Pelvic Organ Prolapse Quantification) examination to assess for prolapse. $^{11}$ 
Women with anatomical evidence of prolapse (POP-Q stage $\geq 1$ ), who had not sought prolapse treatment were potentially eligible. Women were excluded if they had stage 0 or IV prolapse; previous incontinence surgery (except mid-urethral sling operation); previous formal instruction in PFMT for any diagnosis in preceding five years; were planning pregnancy, pregnant, or delivered a baby within the last six months; or unable to give informed consent.

Recruitment to the trial focused on those women who had agreed to have a POP-Q at 12 year follow-up in ProLong. In New Zealand (NZ), all such women were asked to complete a baseline questionnaire and, if eligible on the basis of their response, to attend for a further POP-Q. In the UK, it was not feasible to undertake a further POP-Q for every woman, therefore we used the 12 year POP-Q findings and baseline questionnaire responses to confirm eligibility. A small number of UK women who agreed to a POP-Q, but had not been examined at 12 years, were invited for POP-Q assessment if they were eligible based on their baseline questionnaire responses.

POP-Qs were carried out in Aberdeen by authors $\mathrm{CG}$ and $\mathrm{CH}$, and a nurse and physiotherapist trained to competency by CG; in Birmingham by author PTH, one other experienced urogynaecologist and a POP-Q-trained urogynaecology trainee; and in NZ by author DW and two other gynaecologists trained to competency by DW.

\section{Randomisation and blinding}

Group allocation was generated by a researcher using a password-protected computer program at the Trial Office. Group allocation used minimisation based on: centre, parity ( $\leq 3$ deliveries versus $>3$ ), prolapse stage (above hymen versus at/beyond hymen), and delivery method (any vaginal versus all Caesarean Sections). Women were informed of their group by letter. Treatment could not be concealed from women as the intervention involved attendance at appointments and classes, and daily home exercises. Outcome assessment was by participant-completed postal questionnaires administered at baseline (when randomised), one and two years after randomisation. Researchers conducting data entry were blinded to group allocation. Analysis was conducted by a statistician (AE) blinded to group allocation until after the database was closed.

\section{Procedures}

The intervention consisted of PFMT delivered both one-to-one and in a class setting. Women were offered five appointments with a specialist women's health physiotherapist (intervention physiotherapist) over 16 weeks (weeks 0, 2, 6, 11 and 16), who assessed pelvic floor muscles, taught 
correct exercise technique, prescribed individualised home PFMT programme (three sets of exercises daily, completion of exercise diaries), provided a prolapse lifestyle advice leaflet (focusing on weight loss, avoidance of heavy lifting, constipation, coughing, and high-impact exercise), and tailored lifestyle advice (Phase 1). Intervention group women were then offered modified Pilates classes (with pelvic floor muscle exercises as a key distinct element and an exercise DVD ${ }^{12}$ for home use), and a one-to-one physiotherapy review appointment one and two years after randomisation (Phase 2). Classes were led by specialist women's health physiotherapists trained in Pilates and took place in six-week blocks; each woman was offered two blocks. In NZ, women were offered attendance at existing weekly Pilates exercise classes, led by physiotherapists similarly trained to those in the UK, at the University of Otago School of Physiotherapy clinics, open also to women in the general public.

Control group women received, by post, the same prolapse lifestyle advice leaflet as the intervention group.

All adverse and serious adverse events were recorded on an Adverse Event Form and reported immediately to the Trial Office in terms of seriousness, relatedness to the intervention and any changes made to the treatment.

The primary outcome was prolapse symptom severity (Pelvic Organ Prolapse Symptom Score, POPSS) ${ }^{13}$ at two years. POP-SS is a validated, patient-completed questionnaire with seven items addressing frequency of prolapse symptoms in the previous four weeks; each item is scored from 0 (never) to 4 (all of the time), with a total ranging from $0-28$. Secondary outcomes were prolapserelated quality of life (single item measures scored 0-10, adapted from the International Consultation on Incontinence Questionnaire-Vaginal Symptoms (ICIQ-VS $\left.)^{14}\right)$; and use of primary and secondary care health services for prolapse symptoms. Other outcomes were self-reported health and well-being using a 12 -item short form survey $(\mathrm{SF}-12)^{15}$; lifestyle changes ${ }^{8}$; urinary leakage (including ICIQ-Urinary Incontinence (ICIQ-UI) short-form ${ }^{16}$, ranging from 0-21, higher score indicating greater severity), bowel symptoms (ICIQ-Bowel Symptoms - early short-form version), sexual symptoms (including the short-form Prolapse Incontinence Sexual Questionnaire (PISQ-12) ${ }^{17}$, ranging from 0-48, higher scores indicating greater sexual dysfunction); PFM exercise adherence; and a rating of health benefit (better, same, worse). 
Sample size calculations indicated that 200 per group would provide over $99 \%$ power at a $5 \%$ significance level (two-sided) to detect a difference of 3 in POP-SS scores (standard deviation of 7 assumed) between groups. This was based on the difference observed in our pilot trial of PFMT for treatment of prolapse. ${ }^{18}$ allowing for $10 \%$ loss to follow-up.

\section{Statistical analysis}

Participants with follow-up data were included in the analysis according to the group to which they had been randomised, whether or not they received their allocated intervention. POP-SS scores were compared using repeated measures mixed models with compound symmetry covariance matrices. Other continuous outcomes were analysed using analysis of covariance, and binary/ordinal outcomes were analysed using binary/ordinal logistic regression. All analyses adjusted for age, minimisation variables and baseline measurements. Assumptions of linearity and normality of error distributions were examined by inspection of residual plots in the mixed models and analyses of covariance, and score tests were performed to examine the proportional odds assumptions in the ordinal models. These assumptions were shown to hold.

Sensitivity analyses were conducted to examine the effect of missing POP-SS data under various assumptions. We first assumed that missing data were missing at random using multiple imputation, with subsequent assumptions that data were missing not at random. Missing data were assumed to be better than expected (one point lower than the imputed value assuming missing at random, and similarly one point worse than expected. We also restricted these assumptions of being better and worse to each arm individually.

Sub-group analyses of treatment interactions with age $(<50 / 50$ years +$)$, prolapse stage (above or at the hymen/beyond hymen) ${ }^{19}$, and leading edge of prolapse (anterior/posterior/both) were undertaken.

In the economic evaluation, the SF-12 data were converted to SF-6D using an algorithm from the University of Sheffield (www.shef.ac.uk/scharr/sections/heds/mvh/sf-6d), to allow the estimation of a preference-based single index measure for health using UK population values. ${ }^{20}$ SF-6D scores were averaged and used to calculate the cost per QALY at years one and two. The cost of the intervention was calculated using the Department of Health Reference Costs for 2011/12 (www.gov.uk).

Statistical analysis was conducted, using Stata v13 (StataCorp, College Station, TX, USA). 


\section{Role of funding source}

Study sponsors had no role in design, data collection, analysis, interpretation, or writing of the report. $\mathrm{AE}, \mathrm{SH}$, and $\mathrm{MC}$ had access to trial data and all authors had final responsibility for the decision to submit for publication.

\section{Results}

Between November 2008 and February 2009 in NZ (14 to 15 years after index birth), and October 2010 and February 2011 in the UK (16 to 17 years after index birth), 1130 women were invited to consider taking part in the trial. Five hundred and forty-four women responded to the baseline questionnaire, of whom 130 were ineligible, declined or did not attend for examination. In total, 414 women were randomised between December 2008 and February 2010 (NZ, n=77), and October 2010 and September 2011 (UK, n=337): 207 to intervention, 207 to control. Two women were subsequently found to be ineligible (one intervention, one control) and treated as postrandomisation exclusions, leaving 412 women for inclusion in analysis (Figure 1).

Baseline characteristics are summarised by randomised group in Table 1 . Ninety-seven percent (399/412) of women had prolapse above or at the level of the hymen (186/412, 45\% stage I, $213 / 412,52 \%$ stage II above or at the hymen).

The return rate of questionnaires was $79 \%$ at one year and $84 \%$ at two years. In the intervention group $74 \%$ of women attended three or more of the five appointments offered, $9 \%$ (19) attended no appointments, $44 \%$ (88) attended all five (mean 3.5 appointments, SD 1.7 ), and $65 \%$ returned all their home exercise diaries. Attendance rate at annual physiotherapy review appointments was $52 \%$ and $45 \%$ at year 1 and year 2 respectively, and uptake of classes was $28 \%$ and $15 \%$ at first and second block respectively. At year $2,77 \%$ of women in the intervention group reported they had done PFM exercises in the last four weeks, which was significantly higher than in the control group (53\%) (OR 3.22, 95\% Cl 1.94-5.32, p<0.001).

Three adverse events were reported; all in the intervention group. One woman had a fall the day before attending a Pilates class, one experienced pain in her tail bone during PFMT, and one experienced shortness of breath and chest pain during PFMT. 


\section{Primary outcome measure}

There was a significantly lower POP-SS score at two years in the intervention group compared to the control group (mean difference $-1.01,95 \% \mathrm{Cl}(-1.70$ to -0.33 ), $p=0.004)$ (Table 2), indicating fewer symptoms. The difference at one year was also significant in favour of the intervention group (mean difference $-0.98,95 \% \mathrm{Cl}(-1.61$ to -0.35$), p=0.002)$ (Table 2). Sensitivity analyses to examine the effect of missing POP-SS scores gave estimates of the differences between the groups which were significant and similar to those from the original model, ranging from -1.03 to -0.70 at two years. No significant sub-group interaction effects were found.

\section{Other prolapse-related outcomes}

The individual POP-SS symptoms significantly more common in the control group at two years were 'a feeling of something coming down from or in your vagina' and 'a need to strain (push) to empty your bladder' (Table 3). The prevalence of these symptoms tended to decrease over time in the intervention group, but stayed constant in the control group. Overall, the symptom most commonly reported by both groups was 'a feeling that your bowel has not emptied completely' (Table 4).

Women in the intervention group were more likely to say they felt a health-related benefit from the study compared to controls ( $44 \cdot 2 \%$ vs $9 \cdot 8 \%, \mathrm{OR}=7.0$ (95\% Cl 3.9 to 12.8 ), $\mathrm{p}<0 \cdot 001)$.

There were no significant differences at two years between groups in quality of life associated with prolapse symptoms in any domain (Table 5).

Further treatment for prolapse symptoms within the 2 year follow-up was less common in the intervention group $(5.9 \%$ vs $14.4 \%, O R=0.29$ ( $95 \% \mathrm{Cl} 0.12$ to 0.71$), p=0.007)$. Specifically, the rate of GP consultations relating to prolapse symptoms was lower in the intervention group ( $2 \cdot 9 \%$ vs $12 \cdot 2 \%$, $\mathrm{OR}=0.19(95 \% \mathrm{Cl} 0.05$ to 0.67$), p=0.010$ ) (Table 6).

\section{Other secondary outcomes}

There was a significant difference at two years in favour of the intervention group for the ICIQ-UI SF score, which combines urine leakage frequency, amount and associated bother (mean difference $-0.83,95 \% \mathrm{Cl}-1.44$ to $-0.22, \mathrm{p}=0.008)$. No significant difference was found however between the groups in the percentage who experienced any urine leakage or severe incontinence at two years, or the number of pads used weekly (Table 7). Faecal urgency and leakage were not significantly different between groups at two years, but interference associated with bowel symptoms was less in 
the intervention group (mean difference $-0.51(95 \% \mathrm{Cl}-0.96$ to -0.06$), \mathrm{p}=0.026)$. Sexual symptoms did not differ between groups at two years (Table 7). There were greater lifestyle changes in the intervention group in terms of women reducing heavy lifting, changing the way they exercise and attending exercise classes (Table 8).

\section{Economic outcomes}

Cost per QALY was calculated using only the UK data. Cost of the intervention for year 1 includes cost of five physiotherapy appointments, initial appointment letter, prolapse lifestyle advice leaflet, six Pilates-based classes, and physiotherapy review appointment. It is assumed that each woman attends all appointments and classes. The cost of the intervention was calculated at $£ 519$ per year for one woman taking part. The control cost was $f 1$ for the prolapse lifestyle advice leaflet. Thus, at year 1 , the incremental cost of the intervention is f518. Taking into account savings due to intervention group women having significantly fewer GP contacts relating to prolapse, the adjusted incremental cost is $f 514$. There were no significant differences between groups in the SF-6D score at one year (mean difference $0.01(95 \% \mathrm{Cl}-0.01$ to 0.04$), \mathrm{p}=0.351$ ) or 2 year (mean difference -0.01 (95\% $\mathrm{Cl}-0.04$ to 0.02 ), $\mathrm{p}=0.548$ ). The incremental QALYs at year 1 are 0.02 . Dividing the incremental cost by the incremental QALYs gives a cost per QALY of $£ 21,996$. At year 2 , the incremental cost of the intervention is $f 329$ (one physiotherapy review appointment plus six classes in year 2 ) and the incremental QALYs are 0.01 , giving a cost per QALY of $£ 29,409$.

\section{Discussion \\ Main findings}

The prolapse symptom score was less at two years in women randomised to the PFMT intervention. The control group mean symptom score had stayed similar over the study time-points, whereas the intervention group score had decreased (indicating fewer symptoms on average). The difference between the groups was one point in the POP-SS, but this was less than the minimal clinically important difference for the POP-SS of $1 \cdot 5^{21}$. However this MCID value was derived from data on women having surgery for prolapse, and arguably women who are less symptomatic may value a smaller improvement. This assertion is supported by the fact that women in the intervention group were more likely than controls to say they felt a health-related benefit due to the study. Urinary incontinence severity and interference due to bowel symptoms were also significantly less in the intervention group at two years, suggesting additional clinical benefit was gained. There were no differences in the results by sub-group, suggesting that the woman's age, stage of prolapse and 
prolapse leading edge did not alter the intervention effect. Economic analysis suggests such an intervention could be cost-effective, although cost per QALY ranged from $f 21,996$ in year 1 to $£ 29,409$ in year 2, exceeding NICE-recommended cost-effectiveness threshold of $£ 20,000$ (https://www.nice.org.uk/article/pmg6/chapter/7-assessing-cost-effectiveness\#/economic-

evidence-and-guideline-recommendations). However, cost-effectiveness may be increased by future savings from reduced use of healthcare for prolapse symptoms in the intervention group. Further follow-up to determine long-term benefits is planned.

\section{Strengths and limitations}

The main strengths of this trial were its size, internationality, and pragmatic efficient design, which utilised an existing cohort of women to identify potentially suitable participants. It provides important evidence relevant to women who are at risk of prolapse, a growing number due to the ageing population. Our trial was also woman-centred, with participant-reported symptoms as the primary outcome.

We included women based on their POP-Q stage and absence of previous prolapse treatment, regardless of whether they reported symptoms on the POP-SS. The combination of POP-Q stage and previous treatment was the most objective way to identify women at risk of prolapse progression, given that there are no normative data for the POP-SS to suggest a threshold which would be considered symptomatic. Twenty percent of participants, distributed equally across groups, had a baseline POP-SS of zero, but had stage I, II or III prolapse and had not sought treatment. A post-hoc sensitivity analysis removing these women increased the intervention effect size slightly but would not change the conclusions of the trial.

The difference between the UK and NZ timing of pre-trial prolapse assessment was a limitation. The majority of UK women had a POP-Q assessment between 25 and 57 months prior to the trial, whilst all NZ women had a POP-Q immediately prior to trial entry. This POP-Q information was used, along with baseline questionnaire responses, to determine trial eligibility. It is possible that a UK woman's stage of prolapse had changed in the intervening period, either improving or getting worse ${ }^{22}$, however, such women should be equally distributed between the two groups due to randomisation. Moreover, from analysis of the NZ POP-Q data, no woman's prolapse stage changed between the 12 year follow-up time-point and trial entry to either a stage 0 or stage IV, meaning eligibility was not affected, and offering reassurance that this is likely to be true also for UK women. 
An unavoidable limitation was the lack of blinding of the women participating. The implications of unmasked participants are that women may have been more positive/negative in their responses in the knowledge that they were in the intervention/control group respectively. However in a prevention trial this is less problematic than in a treatment trial since women recruited are not seeking treatment and therefore may be less likely to feel that they have been disadvantaged by being in the control group. We provided control group women with a prolapse lifestyle advice leaflet which they would not otherwise have received in an attempt to minimise this possibility further. The intervention group women may have felt they were at an advantage because they knew they were having treatment over and above normal care, and we recognise this may have impacted on their responses. Unfortunately the nature of the intervention makes it impossible to avoid such performance bias.

\section{Interpretation of findings in context of other research}

The last decade has seen a growth in the evidence-base relating to PFMT for prolapse, however most trials relate to treatment of established symptomatic prolapse in clinical populations. ${ }^{23}$ The largest, high quality trials have found PFMT compared to no treatment is effective in reducing prolapse symptoms in women with stage I to III prolapse. ${ }^{7,8}$ Recently other trials of varying size and quality have compared PFMT with active controls such as lifestyle interventions ${ }^{24}$, Pilates ${ }^{25}$, fitness program ${ }^{26}$, or other forms of PFMT ${ }^{27,28,29}$. Again these trials have reported benefits from PFMT, although in some cases the active controls have appeared to do equally well. ${ }^{24,25,29}$

No trial had targeted prolapse prevention prior to PREVPROL commencing. In 2013, B $\varnothing$ published on 175 primiparous women after vaginal delivery to a singleton infant, selected irrespective of whether they had prolapse signs, randomised to supervised PFMT or written PFMT advice (control). ${ }^{30}$ The intervention group attended weekly PFMT classes for four months, and performed home-based exercise, while controls had no supervision. At six months post-partum there was no difference between groups in the prevalence of bulging either inside or outside the vagina, nor in stage II prolapse. Due to the difference in populations between this trial and PREVPROL, the findings are not comparable. In a 2016 trial in 287 primary care older women (mean age 64) with symptomatic mild prolapse (above the hymen), Panman ${ }^{31}$ randomised women to PFMT or watchful waiting. Women in the PFMT group were given an explanation of pelvic floor anatomy and dysfunctions, were taught "the Knack"32, given lifestyle advice, and had visits with the pelvic physiotherapist weekly initially, then at extended intervals. Home PFMT was recommended three to five times a week, twice or 
three times each day. Similar to our findings, at two years women in the intervention group improved their symptom score significantly more than those in the watchful waiting group, and were more likely to report overall symptom improvement.

\section{Implementation}

Although women in our trial had not been seeking treatment, uptake of PFMT appointments was 91\%, around half attended for annual reviews, over half had made at least one lifestyle change to reduce risk of prolapse, and 77\% reported undertaking PFM exercises at two years, suggesting willingness to engage with a prevention intervention. Generalisability of the findings is important to consider however, as we might expect lower uptake than that observed in the trial if the intervention was rolled out to women in the general population.

There was lower uptake of the exercise classes (28\% Year 1 and $15 \%$ Year 2), which were intended to support long-term adherence to PFMT, known to decrease with time. This suggests that the effect of the intervention may be due to its one-to-one components (physiotherapy appointments, prescribed home exercise, and lifestyle discussions). We cannot however say with certainty which part or parts of this complex intervention contributed to the effect observed. This would require further trials targeting individual or combined elements of the intervention.

The optimal "dose" and delivery mode of PFMT for this population is something that requires further research. To reduce the burden for women and costs to the health service we would want to know how much physiotherapist contact and supervision is required to achieve sufficient symptom management and avoidance of more invasive treatments, such as pessaries or surgery.

\section{Conclusions}

We provide evidence that PFMT leads to a small, but likely important reduction in prolapse symptoms, in women with stage I to III prolapse who have not previously sought prolapse treatment. Evidence was also found in the intervention group of less urinary incontinence, less interference due to bowel symptoms, and lower uptake of prolapse treatment. This is important 
information for physiotherapists, gynaecologists, and women generally, to inform decisions about adopting preventive strategies. (word count 3822)

\section{Authors' contributions}

- $\quad$ SH conceived of the trial, was the Chief Investigator of the trial; had complete involvement in and oversight of the study design, execution, and data collection; and was responsible for writing the final manuscript.

- $\quad$ CG conceived of the trial, contributed to the design of the study, and writing of the manuscript, and also to the choice, and design of the outcomes measures.

- $\quad$ DM contributed to the design of the trial overall and the physiotherapy intervention specifically, was responsible for training of the UK physiotherapists delivering the trial intervention, and writing the final manuscript.

- $\quad$ CM, part-funded by the National Institute for Health Research (NIHR) Collaboration for Leadership in Applied Health Research and Care West Midlands, contributed to the design of the study, its delivery, and writing of the manuscript.

- $\quad A E$ did the statistical analysis of the trial data and contributed to the write-up of the methods and results sections.

- $\quad \mathrm{PH}$ contributed to the study design, and the development of the statistical analysis plan and its implementation.

- DW conceived of the trial, contributed to the overall study development, oversight of the trial delivery in New Zealand, and writing of the final manuscript.

- $\quad$ PTH was local Principal Investigator in Birmingham, was responsible for local set up and delivery of the trial, and contributed to the final manuscript.

- $\quad \mathrm{CH}$ was local Principal Investigator in Aberdeen, was responsible for local set up and delivery of the trial, and contributed to the final manuscript.

- JHS contributed to the design of the trial overall and the physiotherapy intervention specifically, was responsible for training of the NZ physiotherapists delivering the trial intervention, and writing the final manuscript.

- $\quad \mathrm{MC}$ designed and analysed the health economics component of the study and wrote the health economics sections in collaboration with the Chief Investigator

- $\quad$ SD (the UK trial coordinator) was responsible for the day-to-day management of all aspects of the trial, centre initiation visits, and the trial office, and also contributed to writing of the final manuscript. 
- $\quad J L$ assisted with day-to-day trial management, liaised with centre staff, undertook data reporting, and contributed to the final manuscript.

\section{Conflict of interest statements}

We declare that we have no conflicts of interest.

\section{Ethics committee approval}

Ethical approval was granted in the UK by the Scotland Research Ethics Committee A (10/MRE00/53), and by the Lower South Regional Ethics Committee, Ministry of Health, Dunedin in NZ.

\section{Acknowledgements}

We acknowledge funding for the trial from the Wellbeing of Women charity, the New Zealand Continence Association, and the Dean's Bequest Fund of Dunedin School of Medicine. We thank all the women who willingly participated in the trial and completed their questionnaires and attended physiotherapy and classes; the staff at each of our centres for recruiting, motivating and treating our participants (Diane Stark, Nina Bridges, Emma James, Helene Simmons, Kumbi Gwatidzo, Jenny Corbett, Sandra Whyte, Elizabeth Crothers, Gail Hyland, Leslie Inglis and Evelyn Tulloch); those who carried out POP-Q assessments (Nicola Dean, Helen Paterson, Matthew Parsons, Karen Richardson, Elizabeth Crothers); staff who assisted the trial office in the UK (Gladys McPherson, Nicole Sergenson, Anne Taylor); those who administered the trial in Dunedin (Gaye Ellis), and members of the trial steering committee and data monitoring committee for giving their time in advising the trial team throughout the work. 


\section{Figures and tables}

Figure 1.

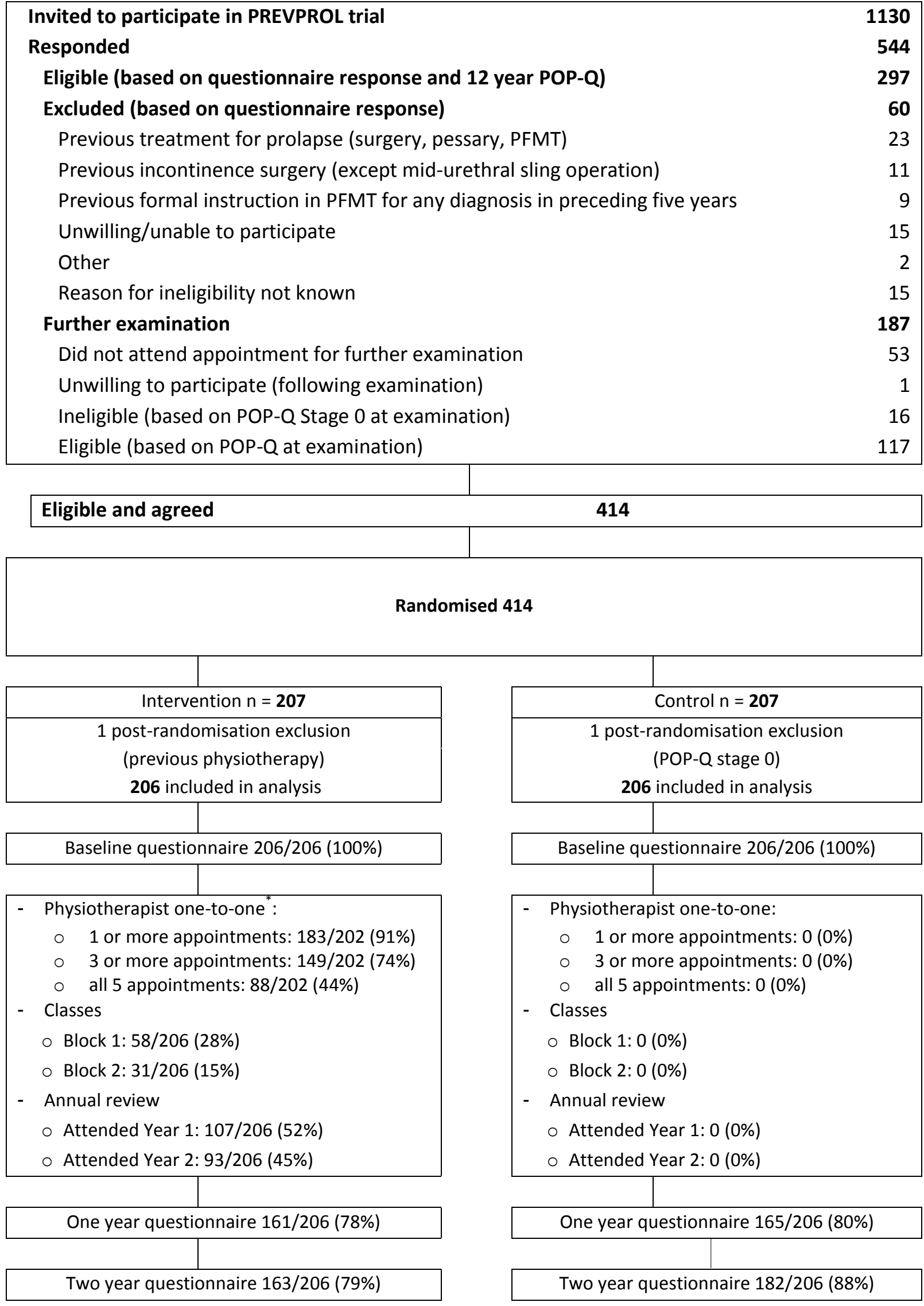


* forms missing for 4 women

Table 1. Baseline characteristics of randomised women

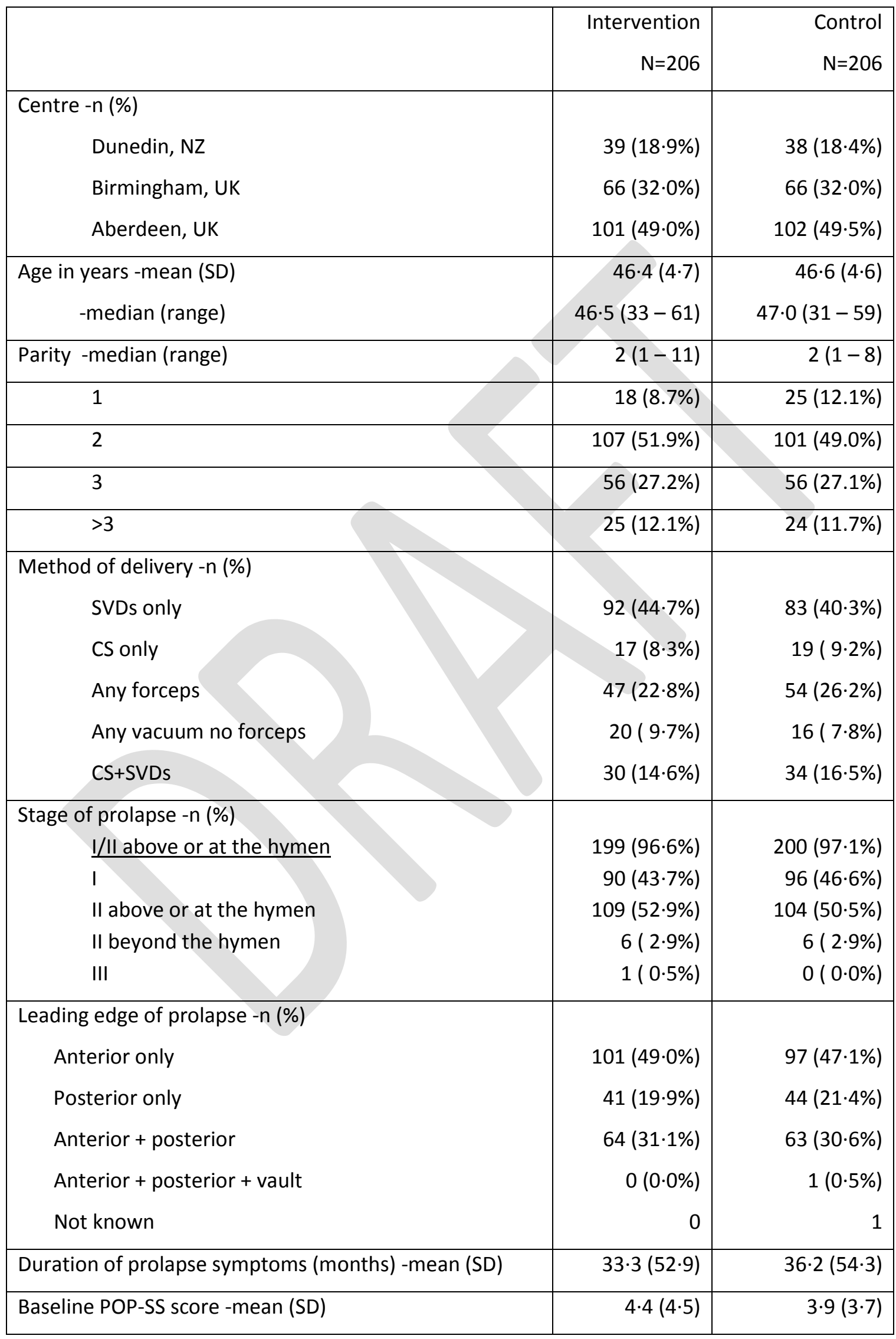


Baseline POP-SS score $=0-n(\%)$

$S V D=$ spontaneous vaginal delivery

$\mathrm{CS}=$ caesarean section

POP-SS=pelvic organ prolapse symptom score

$\mathrm{SD}=$ standard deviation

Table 2 Prolapse symptoms (POP-SS score) reported in baseline, Year 1 and Year 2 questionnaires

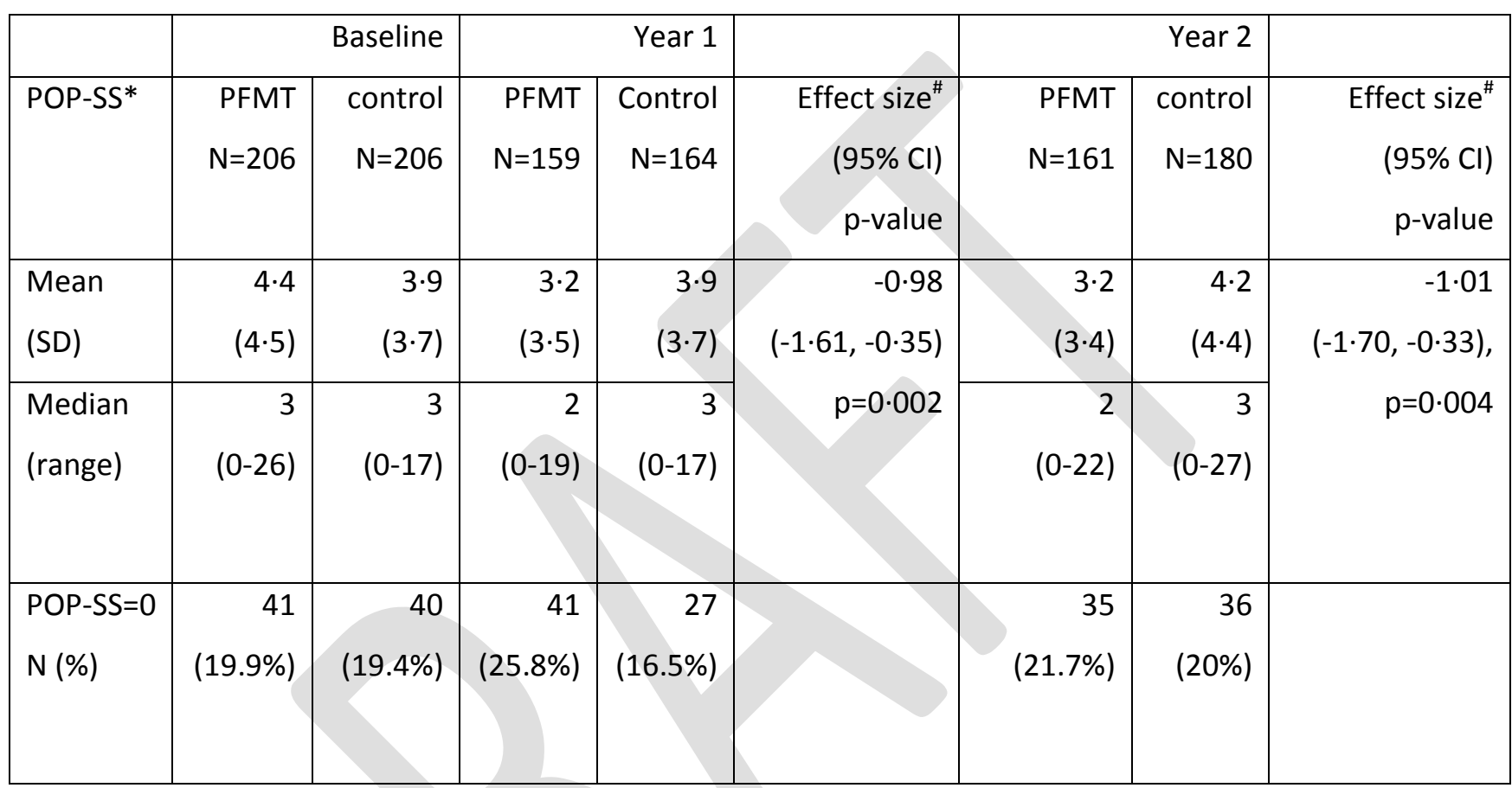

*POP-SS score, $0=$ no symptoms, 28 = all symptoms all the time

${ }^{\#}$ Estimated effect of intervention on POP-SS (from repeated measures model)

Table 3 Comparison between groups of each POP-SS symptom at 2 years

\begin{tabular}{|l|c|c|c|c|}
\hline Symptom at year 2 & OR $^{*}$ & \multicolumn{2}{|c|}{$95 \% \mathrm{Cl}$} & p-value \\
\hline Something coming down & 0.40 & 0.23 & 0.73 & 0.002 \\
\hline Discomfort worse when standing & 0.71 & 0.33 & 1.51 & 0.374 \\
\hline Abdominal pain when standing & 0.60 & 0.36 & 1.01 & 0.056 \\
\hline Lower back heaviness & 0.63 & 0.37 & 1.05 & 0.076 \\
\hline Strain to empty bladder & 0.41 & 0.24 & 0.69 & 0.001 \\
\hline Feel bladder not empty & 0.65 & 0.42 & 1.01 & 0.058 \\
\hline Feel bowel not empty & 0.89 & 0.58 & 1.36 & 0.587 \\
\hline
\end{tabular}

*Odds ratios from the ordinal regression model of less than

one favour the intervention group 
Table 4 Individual prolapse symptoms reported in baseline, Year 1 and Year 2 questionnaires

\begin{tabular}{|c|c|c|c|c|c|c|c|}
\hline \multirow{2}{*}{\multicolumn{2}{|c|}{ Prolapse symptom }} & \multicolumn{3}{|c|}{ Intervention } & \multicolumn{3}{|c|}{ Control } \\
\hline & & $\begin{array}{r}\text { Baseline } \\
N=206\end{array}$ & $\begin{array}{l}\text { Year } 1 \\
N=161\end{array}$ & $\begin{array}{l}\text { Year } 2 \\
N=163\end{array}$ & $\begin{array}{r}\text { Baseline } \\
\mathrm{N}=206\end{array}$ & $\begin{array}{l}\text { Year } 1 \\
N=165\end{array}$ & $\begin{array}{l}\text { Year } 2 \\
\mathrm{~N}=182\end{array}$ \\
\hline Something coming down & $\begin{array}{l}\text { Score - mean (SD) } \\
\text { Any symptom - } n(\%) \\
\text { Most or all the time - } n(\%)\end{array}$ & $\begin{array}{r}0 \cdot 4(0 \cdot 7) \\
55(26 \cdot 7 \%) \\
5(2 \cdot 4 \%)\end{array}$ & $\begin{array}{r}0.3(0 \cdot 6) \\
32(19.9 \%) \\
3(1.9 \%)\end{array}$ & $\begin{array}{r}0 \cdot 2(0 \cdot 6) \\
27(16 \cdot 6 \%) \\
3(1 \cdot 8 \%)\end{array}$ & \begin{tabular}{|r|}
$0 \cdot 3(0 \cdot 7)$ \\
$50(25 \cdot 1 \%)$ \\
$1(0 \cdot 5 \%)$
\end{tabular} & $\begin{array}{r}0 \cdot 3(0 \cdot 6) \\
42(25 \cdot 5 \%) \\
2(1 \cdot 2 \%)\end{array}$ & $\begin{array}{r}0 \cdot 4(0 \cdot 8) \\
52(28 \cdot 6 \%) \\
5(2 \cdot 8 \%)\end{array}$ \\
\hline Discomfort worse when standing & $\begin{array}{l}\text { Score - mean (SD) } \\
\text { Any symptom - } n(\%) \\
\text { Most or all the time - } n(\%)\end{array}$ & $\begin{array}{r}0.3(0 \cdot 6) \\
42(20 \cdot 4 \%) \\
2(1 \cdot 0 \%)\end{array}$ & $\begin{array}{r}0 \cdot 1(0.5) \\
16(9.9 \%) \\
1(0.6 \%)\end{array}$ & $\begin{array}{r}0.1(0.4) \\
17(10 \cdot 4 \%) \\
0(0.0 \%)\end{array}$ & $\begin{array}{r}0 \cdot 2(0.5) \\
34(17 \cdot 1 \%) \\
0(0.0 \%)\end{array}$ & $\begin{array}{r}0.2(0.5) \\
27(16 \cdot 4 \%) \\
1(0.6 \%)\end{array}$ & $\begin{array}{r}0 \cdot 2(0 \cdot 6) \\
24(13 \cdot 2 \%) \\
3(1 \cdot 7 \%)\end{array}$ \\
\hline Abdominal pain when standing & $\begin{array}{l}\text { Score - mean (SD) } \\
\text { Any symptom - } n(\%) \\
\text { Most or all the time - } n(\%)\end{array}$ & $\begin{array}{r}0.6(0 \cdot 8) \\
86(41 \cdot 8 \%) \\
5(2 \cdot 4 \%)\end{array}$ & $\begin{array}{r}0 \cdot 3(0 \cdot 6) \\
39(24 \cdot 2 \%) \\
2(1 \cdot 2 \%)\end{array}$ & \begin{tabular}{r|}
$0.3(0 \cdot 6)$ \\
$47(28 \cdot 8 \%)$ \\
$5(2 \cdot 8 \%)$
\end{tabular} & \begin{tabular}{|r|}
$0 \cdot 4(0 \cdot 7)$ \\
$64(32 \cdot 2 \%)$ \\
$3(1 \cdot 5 \%)$
\end{tabular} & $\begin{array}{r}0.4(0.7) \\
54(32 \cdot 7 \%) \\
3(1.8 \%)\end{array}$ & $\begin{array}{r}0.4(0 \cdot 8) \\
57(31 \cdot 3 \%) \\
6(0 \cdot 0 \%)\end{array}$ \\
\hline Lower back heaviness & $\begin{array}{l}\text { Score - mean (SD) } \\
\text { Any symptom - } n(\%) \\
\text { Most or all the time - } n(\%)\end{array}$ & $\begin{array}{r}0.6(0.9) \\
70(34.0 \%) \\
9(4.4 \%)\end{array}$ & $\begin{array}{r}0.4(0 \cdot 7) \\
45(28 \cdot 0 \%) \\
2(1 \cdot 2 \%)\end{array}$ & $\begin{array}{r}0 \cdot 4(0 \cdot 8) \\
45(27 \cdot 6 \%) \\
5(3 \cdot 1 \%)\end{array}$ & \begin{tabular}{r|}
$0.4(0 \cdot 8)$ \\
$61(30 \cdot 7 \%)$ \\
$4(2 \cdot 0 \%)$
\end{tabular} & $\begin{array}{r}0.4(0.7) \\
54(32 \cdot 7 \%) \\
2(1 \cdot 2 \%)\end{array}$ & $\begin{array}{r}0.5(0.9) \\
63(34 \cdot 6 \%) \\
9(5 \cdot 0 \%)\end{array}$ \\
\hline Strain to empty bladder & $\begin{array}{l}\text { Score - mean (SD) } \\
\text { Any symptom - } n(\%) \\
\text { Most or all the time - } n(\%)\end{array}$ & $\begin{array}{r}0.6(0.9) \\
84(40 \cdot 8 \%) \\
13(6 \cdot 3 \%)\end{array}$ & $\begin{array}{r}0.5(0 \cdot 8) \\
55(34 \cdot 2 \%) \\
3(1.9 \%)\end{array}$ & $\begin{array}{r}0 \cdot 4(0 \cdot 8) \\
44(27 \cdot 0 \%) \\
5(3 \cdot 1 \%)\end{array}$ & $\begin{array}{r}0 \cdot 6(0.9) \\
80(40 \cdot 2 \%) \\
10(5 \cdot 0 \%)\end{array}$ & $\begin{array}{r}0.7(0 \cdot 9) \\
74(44 \cdot 9 \%) \\
7(4 \cdot 2 \%)\end{array}$ & $\begin{array}{r}0 \cdot 7(0.9) \\
73(40 \cdot 6 \%) \\
10(5 \cdot 5 \%)\end{array}$ \\
\hline Feel bladder not empty & $\begin{array}{l}\text { Score - mean (SD) } \\
\text { Any symptom - } n(\%)\end{array}$ & $\begin{array}{r}0 \cdot 8(1 \cdot 0) \\
107\end{array}$ & $\begin{array}{r}0.6(0 \cdot 8) \\
72(44 \cdot 7 \%)\end{array}$ & $\begin{array}{r}0.6(0.8) \\
75(46 \cdot 0 \%)\end{array}$ & \begin{tabular}{r|}
$0 \cdot 8(0.9)$ \\
111
\end{tabular} & $\begin{array}{r}0.9(0.9) \\
93(56.4 \%)\end{array}$ & $\begin{array}{r}0.9(0.9) \\
103\end{array}$ \\
\hline
\end{tabular}




\begin{tabular}{|c|c|c|c|c|c|c|c|}
\hline & Most or all the time $-n(\%)$ & $\begin{array}{r}(51 \cdot 9 \%) \\
17(8 \cdot 3 \%)\end{array}$ & $4(2 \cdot 5 \%)$ & $5(3 \cdot 1 \%)$ & $\begin{array}{r}(55 \cdot 8 \%) \\
13(6 \cdot 5 \%)\end{array}$ & $11(6 \cdot 7 \%)$ & $\begin{array}{r}(56 \cdot 6 \%) \\
14(7 \cdot 7 \%)\end{array}$ \\
\hline Feel bowel not empty & $\begin{array}{l}\text { Score - mean (SD) } \\
\text { Any symptom - } n(\%) \\
\text { Most or all the time - } n(\%)\end{array}$ & $\begin{array}{r}1 \cdot 1(1 \cdot 0) \\
139 \\
(67 \cdot 5 \%) \\
17(8 \cdot 3 \%)\end{array}$ & $\begin{array}{r}0.9(0.9) \\
93(57 \cdot 8 \%) \\
9(5.6 \%)\end{array}$ & $\begin{array}{r}1 \cdot 0(0 \cdot 9) \\
106 \\
(65 \cdot 0 \%) \\
7(4 \cdot 3 \%)\end{array}$ & $\begin{array}{r}1 \cdot 0(1 \cdot 0) \\
128 \\
(64 \cdot 3 \%) \\
14(7 \cdot 0 \%)\end{array}$ & $\begin{array}{r}0.9(0.9) \\
102 \\
(61 \cdot 8 \%) \\
10(6 \cdot 1 \%)\end{array}$ & $\begin{array}{r}1 \cdot 0(1 \cdot 0) \\
115 \\
(63 \cdot 2 \%) \\
14(7 \cdot 7 \%)\end{array}$ \\
\hline
\end{tabular}

Table 5 Summary of prolapse-related quality of life scores in baseline and Year 2 questionnaires (N, mean, SD)

\begin{tabular}{|c|c|c|c|c|c|}
\hline Quality of Life* & $\begin{array}{c}\text { Base } \\
\text { Intervention }\end{array}$ & $\begin{array}{l}\text { e } \\
\text { Control }\end{array}$ & $\begin{array}{l}\text { Ye } \\
\text { Intervention }\end{array}$ & Control & Mean difference at 2 years \\
\hline Prolapse interferes with physical activity & $\begin{array}{c}\mathrm{N}=194 \\
0.8(2.1)\end{array}$ & $\begin{array}{l}\mathrm{N}=194 \\
0.6(1.7)\end{array}$ & $\begin{array}{l}\mathrm{N}=166 \\
0.6(1.6)\end{array}$ & $\begin{array}{l}\mathrm{N}=178 \\
0.8(1.9)\end{array}$ & $-0.18(95 \% \mathrm{Cl}-0.51$ to 0.15$), p=0.286$ \\
\hline Prolapse interferes with social activity & $\begin{array}{c}N=191 \\
0.5(1.6)\end{array}$ & $\begin{array}{c}N=195 \\
0.5(1.6)\end{array}$ & $\begin{array}{c}N=166 \\
0.4(1.4)\end{array}$ & $\begin{array}{c}\mathrm{N}=178 \\
0.5(1.6)\end{array}$ & $0.01(95 \% \mathrm{Cl}-0.25$ to 0.28$), p=0.915$ \\
\hline Prolapse interferes with personal hygiene & $\begin{array}{l}\mathrm{N}=192 \\
0.6(1.8)\end{array}$ & $\begin{array}{l}\mathrm{N}=195 \\
0.7(1.9)\end{array}$ & $\begin{array}{l}\mathrm{N}=166 \\
0.5(1.3)\end{array}$ & $\begin{array}{c}\mathrm{N}=178 \\
0.6(1.7)\end{array}$ & $-0.06(95 \% \mathrm{Cl}-0.35$ to 0.23$), p=0.679$ \\
\hline Prolapse interferes with everyday life & $\begin{array}{l}\mathrm{N}=193 \\
0.8(1.9)\end{array}$ & $\begin{array}{l}\mathrm{N}=195 \\
0.6(1.6)\end{array}$ & $\begin{array}{l}\mathrm{N}=166 \\
0.5(1.4)\end{array}$ & $\begin{array}{l}\mathrm{N}=178 \\
0.7(1.7)\end{array}$ & $-0.13(95 \% \mathrm{Cl}-0.41$ to 0.14$), p=0.344$ \\
\hline
\end{tabular}

"Each item response ranges from 0 "not at all" to 10 "a great deal", or "not applicable". If "not-applicable", then the score is assumed to be zero. 
Table $6 \quad$ Uptake of treatment for prolapse symptoms (during year 1 and year 2 of follow-up)

\begin{tabular}{|c|c|c|c|c|c|c|c|}
\hline & \multicolumn{2}{|c|}{ In Year 1} & \multicolumn{2}{|c|}{ In Year 2} & \multicolumn{3}{|c|}{ Within 2 years } \\
\hline & $\frac{\text { Intervention }}{\mathrm{n} / \mathrm{N}(\%)}$ & $\begin{array}{l}\text { Control } \\
n / N(\%)\end{array}$ & $\begin{array}{c}\text { Intervention } \\
\mathrm{n} / \mathrm{N}(\%)\end{array}$ & $\frac{\text { Control }}{n / N(\%)}$ & $\begin{array}{c}\frac{\text { Intervention }}{\mathrm{n} / \mathrm{N}(\%)} \\
\text { (\%) }\end{array}$ & $\begin{array}{l}\frac{\text { Control }}{n / N(\%)} \\
\text { n }\end{array}$ & $\begin{array}{c}\text { Odds ratio } \\
\text { Od } \\
(95 \% \mathrm{Cl}), p \text {-value }\end{array}$ \\
\hline ANY TREATMENT ${ }^{1}$ & $4 / 158(2 \cdot 5 \%)$ & $13 / 163(8.0 \%)$ & $10 / 164(6 \cdot 1 \%)$ & $17 / 176(10 \cdot 2 \%)$ & $8 / 135$ (5.9\%) & $22 / 153(14 \cdot 4 \%)$ & $0.29(95 \% \mathrm{Cl} 0.12$ to 0.71$), p=0.007$ \\
\hline Surgery $^{2}$ & $0 / 153(0.0 \%)$ & $1 / 153(0 \cdot 7 \%)$ & $0 / 163(0 \cdot 0 \%)$ & $1 / 171(0.6 \%)$ & $0 / 131(0.0 \%)$ & $1 / 143(0 \cdot 7 \%)$ & $n / a$ \\
\hline Pessary $^{2}$ & $0 / 158(0 \cdot 0 \%)$ & $0 / 163(0 \cdot 0 \%)$ & $0 / 164(0 \cdot 0 \%)$ & $2 / 175(1 \cdot 1 \%)$ & $0 / 135(0.0 \%)$ & $2 / 153(1 \cdot 3 \%)$ & $\mathrm{n} / \mathrm{a}$ \\
\hline Physio referral & $0 / 124(0 \cdot 0 \%)$ & $5 / 134(3 \cdot 7 \%)$ & $4 / 162(2 \cdot 5 \%)$ & $8 / 170(4 \cdot 7 \%)$ & $1 / 108(0.9 \%)$ & $7 / 125(5 \cdot 6 \%)$ & $0.14(95 \% \mathrm{Cl} 0.02$ to 1.20$), \mathrm{p}=0.074$ \\
\hline Practice nurse & $0 / 126(0 \cdot 0 \%)$ & $1 / 137(0 \cdot 7 \%)$ & $4 / 161(2 \cdot 5 \%)$ & $7 / 173(4 \cdot 0 \%)$ & $2 / 110(1 \cdot 8 \%)$ & $5 / 128(3 \cdot 9 \%)$ & $0.37(95 \% \mathrm{Cl} 0.07$ to 2.05$), \mathrm{p}=0.257$ \\
\hline Continence nurse & $0 / 122(0 \cdot 0 \%)$ & $1 / 130(0 \cdot 8 \%)$ & $3 / 161(1 \cdot 9 \%)$ & $1 / 169(0 \cdot 6 \%)$ & $0 / 106(0 \cdot 0 \%)$ & $0 / 121(0 \cdot 0 \%)$ & $n / a$ \\
\hline GP & $2 / 126(1 \cdot 6 \%)$ & $8 / 140(5 \cdot 7 \%)$ & $8 / 158(5 \cdot 1 \%)$ & $17 / 176(9 \cdot 7 \%)$ & $3 / 105(2 \cdot 9 \%)$ & $16 / 131(12 \cdot 2 \%)$ & $0.19(95 \% \mathrm{Cl} 0.05$ to 0.67$), \mathrm{p}=0.010$ \\
\hline Gynaecologist & $0 / 110(0 \cdot 0 \%)$ & $2 / 124(1 \cdot 6 \%)$ & $2 / 147(1 \cdot 4 \%)$ & $3 / 159(1 \cdot 9 \%)$ & $2 / 97(2 \cdot 1 \%)$ & $3 / 116(2 \cdot 6 \%)$ & $0.74(95 \% \mathrm{Cl} 0.12$ to 4.64$), \mathrm{p}=0.750$ \\
\hline Other treatment ${ }^{3}$ & $1 / 110(0 \cdot 9 \%)$ & $2 / 124(1 \cdot 6 \%)$ & $0 / 147(0 \cdot 0 \%)$ & $1 / 159(0 \cdot 6 \%)$ & $1 / 97(1 \cdot 0 \%)$ & $2 / 116(1 \cdot 7 \%)$ & $0.95(95 \% \mathrm{Cl} 0.07$ to 12.12$), \mathrm{p}=0.965$ \\
\hline Not specified & $1 / 110(0 \cdot 9 \%)$ & $0 / 124(0.0 \%)$ & $4 / 147$ (2.7\%) & $0 / 159(0.0 \%)$ & $2 / 97(2 \cdot 0 \%)$ & $0 / 116(0.0 \%)$ & $\mathrm{n} / \mathrm{a}$ \\
\hline
\end{tabular}

${ }^{1}$ At one year the odds ratio for any treatment is 0.40 (95\% $\mathrm{Cl} 0.14$ to 1.17$), p=0.095$, and at two years the odds ratio is $0.49(95 \% \mathrm{Cl} 0.21$ to $1 \cdot 12), p=0.090 .{ }^{2}$ Only surgery and pessary were included in the $\mathrm{NZ}$

questionnaire at one year. ${ }^{3}$ In the first year, a woman in the intervention group had PFMT, a woman in the control group had laxatives to empty her bowel because of her prolapse, and another woman in the control group had counselling. In the second year, a woman in the control group had PFMT. ${ }^{4}$ Not analysed if there are any zero event rates. 
Table 7

Urinary, bowel and sexual symptoms reported in baseline and year 2 questionnaires

\begin{tabular}{|c|c|c|c|c|c|}
\hline & \multicolumn{2}{|r|}{ Baseline } & \multicolumn{2}{|r|}{ Year 2} & \multirow[t]{2}{*}{ Difference at 2 years } \\
\hline & Intervention & Control & Intervention & Control & \\
\hline Urinary symptoms & & & & & \\
\hline $\begin{array}{l}\text { ICIQ UI SF score* } \\
\text { - mean (SD) }\end{array}$ & $\begin{array}{r}4 \cdot 8(4 \cdot 1) \\
\mathrm{N}=202\end{array}$ & $\begin{array}{r}4 \cdot 2(3 \cdot 9) \\
N=194\end{array}$ & $\begin{array}{r}3 \cdot 3(3 \cdot 3) \\
N=161\end{array}$ & $\begin{array}{r}4 \cdot 1(4 \cdot 1) \\
N=175\end{array}$ & $\begin{array}{l}\text { Mean difference }-0.83 \\
(95 \% \mathrm{Cl}-1.44 \text { to }-0.22), p=0.008\end{array}$ \\
\hline $\begin{array}{l}\text { Any incontinence } \\
-\mathrm{n} / \mathrm{N}(\%)\end{array}$ & $\begin{array}{r}150 / 205 \\
(73 \cdot 2 \%)\end{array}$ & $\begin{array}{r}137 / 198 \\
(69 \cdot 2 \%)\end{array}$ & $\begin{array}{r}107 / 163 \\
(65 \cdot 6 \%)\end{array}$ & $\begin{array}{r}124 / 176 \\
(70 \cdot 5 \%)\end{array}$ & $\begin{array}{l}\mathrm{OR}=0.62 \\
(95 \% \mathrm{Cl} 0.33 \text { to } 1.15), \mathrm{p}=0.128\end{array}$ \\
\hline $\begin{array}{l}\text { Severe incontinence (ICIQ UI } \\
\text { SF score }>=13)-n / N(\%)\end{array}$ & $\begin{array}{r}13 / 202 \\
(6 \cdot 4 \%)\end{array}$ & $\begin{array}{l}6 / 194 \\
(3 \cdot 1 \%)\end{array}$ & $\begin{array}{l}3 / 161 \\
(1.9 \%)\end{array}$ & $\begin{array}{r}10 / 175 \\
(5 \cdot 7 \%)\end{array}$ & $\begin{array}{l}\mathrm{OR}=0.23 \\
\quad(95 \% \mathrm{Cl} 0.05 \text { to } 1.06), \mathrm{p}=0.059\end{array}$ \\
\hline $\begin{array}{l}\text { No. of pads per week for those } \\
\text { that use pads - mean (SD) }\end{array}$ & $\begin{array}{r}9 \cdot 2(5 \cdot 7) \\
N=36\end{array}$ & $\begin{array}{r}7 \cdot 4(7 \cdot 7) \\
N=41\end{array}$ & $\begin{array}{r}8 \cdot 5(5 \cdot 8) \\
N=39\end{array}$ & $\begin{array}{r}7 \cdot 4(7 \cdot 7) \\
N=48\end{array}$ & $\begin{array}{l}\text { Mean difference } 0.52 \\
(95 \% \mathrm{Cl}-1 \cdot 81 \text { to } 2 \cdot 85), p=0.653\end{array}$ \\
\hline Bowel symptoms & & & & & \\
\hline $\begin{array}{l}\text { Faecal urgency }\left(\text { any }^{\#}\right) \\
-n / N(\%)\end{array}$ & \begin{tabular}{r|}
$126 / 204$ \\
$(61 \cdot 8 \%)$
\end{tabular} & $\begin{array}{r}116 / 199 \\
(58 \cdot 3 \%)\end{array}$ & $\begin{array}{l}92 / 164 \\
(56 \cdot 1 \%)\end{array}$ & $\begin{array}{l}96 / 176 \\
(54 \cdot 5 \%)\end{array}$ & $\begin{array}{l}\text { OR=1.06 } \\
(95 \% \mathrm{Cl} 0.61 \text { to } 1.86), p=0.835\end{array}$ \\
\hline $\begin{array}{l}\text { Faecal urgency } \\
\text { (most/all of the time) - } \mathrm{n} / \mathrm{N}(\%)\end{array}$ & $\begin{array}{l}9 / 204 \\
(4 \cdot 4 \%)\end{array}$ & $\begin{array}{l}8 / 199 \\
(4 \cdot 0 \%)\end{array}$ & $\begin{array}{l}5 / 164 \\
(3 \cdot 0 \%)\end{array}$ & $\begin{array}{l}9 / 176 \\
(5 \cdot 1 \%)\end{array}$ & $\begin{array}{l}\text { OR }=0.64 \\
(95 \% \mathrm{Cl} 0 \cdot 19 \text { to } 2 \cdot 13), p=0 \cdot 465\end{array}$ \\
\hline $\begin{array}{l}\text { Faecal incontinence }\left(\text { any }^{\#}\right) \\
-n / N(\%)\end{array}$ & $\begin{array}{l}39 / 204 \\
(19 \cdot 1 \%)\end{array}$ & $\begin{array}{l}43 / 194 \\
(22 \cdot 2 \%)\end{array}$ & $\begin{array}{l}32 / 165 \\
(19 \cdot 4 \%)\end{array}$ & $\begin{array}{l}41 / 177 \\
(23 \cdot 2 \%)\end{array}$ & $\begin{array}{l}\mathrm{OR}=0 \cdot 74 \\
(95 \% \mathrm{Cl} 0.37 \text { to } 1.47), p=0.388\end{array}$ \\
\hline Passive $\mathrm{FI}-\mathrm{n} / \mathrm{N}(\%)$ & $\begin{array}{l}33 / 204 \\
(16 \cdot 2 \%)\end{array}$ & $\begin{array}{l}35 / 194 \\
(18 \cdot 0 \%)\end{array}$ & $\begin{array}{l}26 / 164 \\
(15 \cdot 9 \%)\end{array}$ & $\begin{array}{l}32 / 176 \\
(18 \cdot 2 \%)\end{array}$ & $\begin{array}{l}\text { OR }=0.79 \\
(95 \% \mathrm{Cl} 0.39 \text { to } 1.56), p=0.493\end{array}$ \\
\hline Active $\mathrm{FI}-\mathrm{n} / \mathrm{N}(\%)$ & $\begin{array}{l}6 / 204 \\
(2 \cdot 9 \%)\end{array}$ & $\begin{array}{l}8 / 194 \\
(4 \cdot 1 \%)\end{array}$ & $\begin{array}{l}5 / 164 \\
(3 \cdot 0 \%)\end{array}$ & $\begin{array}{l}9 / 176 \\
(5 \cdot 1 \%)\end{array}$ & $\begin{array}{l}\text { OR=0.76 } \\
(95 \% \mathrm{Cl} 0.21 \text { to } 2.75), p=0.675\end{array}$ \\
\hline $\begin{array}{l}\text { Faecal incontinence (severe }{ }^{\# \#} \text { ) } \\
-n / N(\%)\end{array}$ & $\begin{array}{l}8 / 204 \\
(3 \cdot 9 \%)\end{array}$ & $\begin{array}{l}9 / 194 \\
(4 \cdot 6 \%)\end{array}$ & $\begin{array}{l}7 / 165 \\
(4 \cdot 2 \%)\end{array}$ & $\begin{array}{r}10 / 177 \\
(5 \cdot 6 \%)\end{array}$ & $\begin{array}{l}\text { OR }=0.97 \\
(95 \% \mathrm{Cl} 0.31 \text { to } 3.01), p=0.959\end{array}$ \\
\hline $\begin{array}{l}\text { Bowel symptoms interfere } \\
\text { with everyday life }{ }^{* *}-\text { mean } \\
\text { (SD) }\end{array}$ & $\begin{array}{r}1 \cdot 4(2 \cdot 0) \\
\mathrm{N}=164\end{array}$ & $\begin{array}{r}1.3(1 \cdot 9) \\
N=150\end{array}$ & $\begin{array}{r}1 \cdot 1(1 \cdot 6) \\
N=131\end{array}$ & $\begin{array}{r}1 \cdot 5(2 \cdot 4) \\
N=137\end{array}$ & $\begin{array}{l}\text { Mean difference }-0.51 \\
(95 \% \mathrm{Cl}-0.96 \text { to }-0.06) \\
p=0.026\end{array}$ \\
\hline Sexual symptoms & & & & & \\
\hline $\begin{array}{l}\text { Sexually inactive due to } \\
\text { prolapse - } \mathrm{n} / \mathrm{N}(\%)\end{array}$ & $\begin{array}{l}1 / 205 \\
(0 \cdot 5 \%)\end{array}$ & $\begin{array}{l}1 / 199 \\
(0 \cdot 5 \%)\end{array}$ & $\begin{array}{l}5 / 162 \\
(3 \cdot 1 \%)\end{array}$ & $\begin{array}{l}9 / 177 \\
(5 \cdot 1 \%)\end{array}$ & $\begin{array}{l}\text { OR }=0.71 \\
(95 \% \mathrm{Cl} 0.24 \text { to } 2 \cdot 16), p=0.548\end{array}$ \\
\hline
\end{tabular}




\begin{tabular}{|c|c|c|c|c|c|}
\hline $\begin{array}{l}\text { PISQ-12 sexual function score } \\
\text { - mean (SD) }\end{array}$ & $\begin{array}{r}36 \cdot 4(5 \cdot 9) \\
N=168\end{array}$ & $\begin{array}{r}36 \cdot 6(6 \cdot 1) \\
N=158\end{array}$ & $\begin{array}{r}38 \cdot 7(4 \cdot 4) \\
N=128\end{array}$ & $\begin{array}{r}38 \cdot 4(5 \cdot 0) \\
N=134\end{array}$ & $\begin{array}{l}\text { Mean difference }=0.38 \\
(95 \% \mathrm{Cl}-0.44 \text { to } 1.20), p=0.363\end{array}$ \\
\hline $\begin{array}{l}\text { Prolapse symptoms interfere } \\
\text { with sex life } \$ \$ \text { - } / N(\%)\end{array}$ & $\begin{array}{l}26 / 159 \\
(16 \cdot 4 \%)\end{array}$ & $\begin{array}{l}24 / 152 \\
(15 \cdot 8 \%)\end{array}$ & $\begin{array}{l}25 / 148 \\
(16 \cdot 7 \%)\end{array}$ & $\begin{array}{l}32 / 162 \\
(19 \cdot 8 \%)\end{array}$ & $\begin{array}{l}\text { OR }=0.66 \\
(95 \% \mathrm{Cl} 0.31 \text { to } 1.41), p=0.283\end{array}$ \\
\hline
\end{tabular}

*ICIQ UI SF score, $0=$ none, no interference with life to 21=maximum score. Women with no leakage were given a score of zero.

** ranges from 0 "not at all" to 10 "a great deal"

\# occasionally/sometimes/most of the time/all of the time

\#\# sometimes/most of the time/all of the time

$\$$ potential range from 0 to 48, higher score indicates greater sexual dysfunction

$\$$ a little/somewhat/a lot

Table 8: Lifestyle changes

\begin{tabular}{|l|c|c|l|}
\hline \multirow{2}{*}{} & \multicolumn{2}{|c|}{ Year 2 } & \multirow{2}{*}{ Difference at 2 years } \\
\cline { 2 - 3 } & $\frac{\text { Intervention }}{\mathrm{n}(\%)}$ & $\frac{\text { Control }}{\mathrm{n}(\%)}$ & \\
\hline Lost weight & $40 / 156$ & $48 / 163$ & $\mathrm{OR}=0.66$ \\
& $(25 \cdot 6 \%)$ & $(29 \cdot 4 \%)$ & $(95 \% \mathrm{Cl} 0.38$ to $1 \cdot 13), \mathrm{p}=0 \cdot 127$ \\
\hline Avoided/reduced heavy & $55 / 155$ & $32 / 157$ & $\mathrm{OR}=1.96$ \\
lifting & $(35 \cdot 5 \%)$ & $(20 \cdot 4 \%)$ & $(95 \% \mathrm{Cl} 1.13$ to 3.39), $\mathrm{p}=0.017$ \\
\hline Changed the way you & $68 / 148$ & $52 / 149$ & $\mathrm{OR}=1.68$ \\
exercise & $(45.9 \%)$ & $(34.9 \%)$ & $(95 \% \mathrm{Cl} 1.01$ to $2 \cdot 80), \mathrm{p}=0.046$ \\
\hline Attended exercise class & $95 / 163$ & $75 / 174$ & $\mathrm{OR}=2.25$ \\
& $(58.3 \%)$ & $(43.1 \%)$ & $(95 \% \mathrm{Cl} 1.40$ to 3.60), $\mathrm{p}=0.001$ \\
\hline
\end{tabular}




\section{References}

1 Haylen BT, Maher CF, Barber MD et al, 2016. An International Urogynecological Association (IUGA)/International Continence Society (ICS) joint report on the terminology for female pelvic organ prolapse (POP). Neurourol Urodyn 2016; 35(2): 137-168.

2 Hendrix SL, Clark A, Nygaard I, Aragaki A, Barnabei V, McTiernan A. Pelvic organ prolapse in the Women's Health Initiative: gravity and gravidity. Am J Obstet Gynecol 2002; 186(6): 1160-1166.

3 Olsen AL, Smith VJ, Bergstrom JO, Colling JC, Clark AL. Epidemiology of surgically managed pelvic organ prolapse and urinary incontinence. Obstet Gynecol 1997; 89(4): 501-506.

4 Health and Social Care Information Centre. Hospital episode statistics, admitted patient careEngland, 2012-13. Nov 5, 2013. http://www.hscic.gov.uk/ (accessed June 27, 2016).

5 Borello-France DF, Handa VL, Brown MB et al. Pelvic-floor muscle function in women with pelvic organ prolapse. Physical Therapy 2007; 87(4): 399-407.

6 Moore K, Dumoulin C, Bradley C et al. Adult Conservative Management. In: Incontinence, 5th edn. Plymbridge, UK: Health Publication Ltd, 2013, pp 1101-1227.

7 Brækken IH, Memona Majida PT, Engh ME, Bø K. Morphological changes after pelvic floor muscle training measured by 3 dimensional ultrasonography: a randomized controlled trial. Obstet Gynecol 2010; 105(2): 317-324.

8 Hagen S, Stark D, Glazener C et al. Individualised pelvic floor muscle training in women with pelvic organ prolapse (POPPY): a multicentre randomised controlled trial. Lancet 2014; 383:796-806. 9 Hensrud DD. Clinical preventive medicine in primary care: background and practice: 1. Rationale and current preventive practices. Mayo Clinic Proceedings 2000; 75(2): 165-172. 10 MacArthur C, Glazener C, Lancashire R, Herbison P, Wilson D. Exclusive caesarean section delivery and subsequent urinary and faecal incontinence: a 12-year longitudinal study. BJOG 2011; 118(8):1001-7.

11 Bump RC, Mattiasson A, Bo K et al. The standardization of terminology of female pelvic organ prolapse and pelvic floor dysfunction. American Journal of Obstetrics \& Gynecology 1996; 175(1):10-17. 12 SCA Hygiene. CoreWellness programme. http://www.corewellness.co.uk/pelvicoretechnique/order-free-dvd/ (accessed September, 2016).

13 Hagen S, Glazener C, Sinclair L, Stark D, Bugge C. Psychometric properties of the Pelvic Organ Prolapse Symptom Score (POP-SS). BJOG 2009; 116: 25-31.

14 Price N, Jackson SR, Avery K, Brookes ST, Abrams P. Development and psychometric evaluation of the ICIQ Vaginal Symptoms Questionnaire: the ICIQ-VS. BJOG 2006;113(6):700-12.

15 Ware J, Kosinski M, Keller SD (1996). A 12-Item Short-Form Health Survey: construction of scales and preliminary tests of reliability and validity. Medical Care, 34, 220-233. 
16 Avery K, Donovan J, Peters T, Shaw C, Gotoh M, Abrams P. ICIQ: a brief and robust measure for evaluating the symptoms and impact of urinary incontinence. Neurourol Urodyn 2004; 23(4): 322-30. 17 Rogers RG, Coates KW, Kammerer-Doak D, Khalsa S, Qualls C. A short form of the Pelvic Organ Prolapse/Urinary Incontinence Sexual Questionnaire (PISQ-12). Int Urogynecol J Pelvic Floor Dysfunct 2003; 14(3): 164-8.

18 Hagen S, Stark D, Glazener C, Sinclair L, Ramsay I. A randomized controlled trial of pelvic floor muscle training for stages I and II pelvic organ prolapse. Int Urogynecol J 2009;20(1):45-51.

19 Nygaard I, Brubaker L, Zyczynski HM et al. Long-term Outcomes Following Abdominal Sacrocolpopexy for Pelvic Organ Prolapse. JAMA 2013; 309(19):2016-24.

20 Brazier JE, Roberts J. The Estimation of a Preference-Based Measure of Health from the SF-12. Med Care 2004; 42(9): 851-859.

21 Hagen S, Glazener C, Cook J, Herbison P, Toozs-Hobson P. Further properties of the pelvic organ prolapse symptom score: minimally important change and test-retest reliability. Neurourol Urodyn 2010; 29: $1055-56$.

22 Miedel A, Ek M, Tegerstedt G, Mæhle-Schmidt M, Nyrén O, Hammarström M. Short-term natural history in women with symptoms indicative of pelvic organ prolapse. Int Urogynecol J 2011; 22(4): 461-8. 23 Hagen S, Stark D. Conservative prevention and management of pelvic organ prolapse in women. Cochrane Database of Systematic Reviews 2011, Issue 12. Art. No.: CD003882. DOI: 10.1002/14651858.CD003882.pub4.

24 Due U, Brostrom S, Lose G. Lifestyle advice with or without pelvic floor muscle training for pelvic organ prolapse: a randomized controlled trial. Int Urogynecol J 2016; 27: 555-63.

25 Culligan PJ, Scherer J, Dyer $\mathrm{K}$ et al. A randomized clinical trial comparing pelvic floor muscle training to a Pilates exercise program for improving pelvic muscle strength. Int Urogynecol J 2010; 21: 401-8.

26 Alves FK, Riccetto C, Adami DB et al. A pelvic floor muscle training program in postmenopausal women: A randomized controlled trial. Maturitas 2015; 81: 300-5.

27 Resende APM, Stupp L, Bernardes BT et al. Can hypopressive exercises provide additional benefits to pelvic floor muscle training in women with pelvic organ prolapse? Neurourol Urodyn 2012; 31: $121-5$.

28 Giraudo D, Beccaria N, Lamberti G. Pelvic floor muscle training, negative pressure abdominal exercise and pelvic organ prolapse symptoms: A randomized clinical trial. Neurourol Urodyn 2011; 30: 1009-1011.

29 Kashyap R, Jain V, Singh A. Comparative effect of 2 packages of pelvic floor muscle training on the clinical course of stage I to III pelvic organ prolapse. Int J Gynaecol Obstet 2013; 121: 69-73. 
training and pelvic organ prolapse-a randomized trial of primiparous women. Am J Obstet Gynecol 2015; 212: 38.e1-7.

31 Panman CMCR, Wiegersma M, Kollen BJ et al. Two-year effects and cost-effectiveness of pelvic floor muscle training in mild pelvic organ prolapse: a randomised controlled trial in primary care. BJOG 2016; DOI: 10.1111/1471-0528.13992.

32 Miller JM, Ashton-Miller JA, DeLancey JO. A pelvic muscle precontraction can reduce coughrelated urine loss in selected women with mild SUI. J Am Geriatr Soc 1998: 46(7): 870-874.

\title{
Putting research into context
}

\begin{abstract}
Research in context
Evidence before this study

The lead author is also author of the Cochrane review of conservative prevention and management of prolapse. The review, first published in 2006 , found no prevention trials, which informed our decision to conduct the current research. The latest searches for this Cochrane review include a search of the Cochrane Incontinence Group Specialised Trials Register (10 September 2015) with the search strategy developed for the Cochrane Incontinence Review Group, and supplementary searches of CINAHL (from inception to 11 September 2015), PEDro (last searched September 2015), and ZETOC (12 September 2015) with the search terms: cystocele, urethrocele, rectocele, vault prolapse, uterine prolapse, vaginal prolapse, pelvic organ prolapse, pelvic floor. The reference lists of relevant articles were searched. No language or other restrictions were imposed in any of the searches. We have now identified one trial by $B \varnothing$, in an early post-natal population of women, selected irrespective of whether they had prolapse, ${ }^{30}$ and another by Panman in an older population of women in primary care. ${ }^{31}$ The former (judged as low risk for selection, performance, detection, attrition and reporting bias, but unclear for other types of bias) found no benefit at 6 months but was not directly comparable. The latter (judged as low risk for all types of bias), which is more comparable to the current trial found a symptom benefit at 2 years.

Added value of this study

PREVPROL is the largest trial of PFMT for prevention of prolapse and the only one in women with signs of prolapse several years after childbirth. Its results, showing that the intervention had significant symptom benefit, will be added to the Cochrane review currently being updated. Metaanalysis of the primary outcomes from this trial (POP-SS at 2 year follow-up) and the Panman trial ${ }^{31}$ (PFDI-20 at 2 year follow-up) indicated a significant symptom benefit (reduced symptom score) for
\end{abstract}


women who had undertaken PFMT (pooled SMD is -0.23 (95\% $\mathrm{Cl}-0.40$ to -0.07$), \mathrm{p}=0.005)$.

Implications of all the available evidence

PFMT can prevent prolapse symptoms at 2 years after intervention and may reduce the uptake of treatment. Therefore women should be recommended to undertake PFMT even before they have bothersome symptoms. We do not know the long-term benefits as yet, but given that PFMT is safe and can be performed easily by most women, this should be encouraged. Provision of one-to-one teaching of PFMT is needed to support women with prolapse prevention. Qualitative research is needed to find out from women's perspectives what format a prevention intervention should take to maximise uptake and benefit. 